\title{
Optogenetic stimulation inhibits the self-renewal of mouse embryonic stem cells
}

\author{
Shaojun Wang ${ }^{1,2,3}$, Lu Du ${ }^{1}$ and Guang-Hua Peng ${ }^{1,3^{*}}$
}

\begin{abstract}
Modulation of the embryonic stem cell state is beneficial for elucidating the innate mechanisms of development and regenerative medicine. Ion flux plays important roles in modulating the transition between stemness and differentiation in mouse embryonic stem cells (mESCs). Optogenetics is a novel tool for manipulating ion flux. To investigate the impact of optical stimulation on embryonic stem cells, optogenetically engineered V6.5 mESCs were used to measure the depolarization mediated by ChR2 on the proliferation, self-renewal, and differentiation of mESCs. Blue light stimulation significantly inhibited ChR2-GFP-V6.5 ESC proliferation and disrupted the cell cycle progression, reducing the proportion of cells in the S phase. Interestingly, optical stimulation could inhibit ChR2-GFP-V6.5 ESC self-renewal and trigger differentiation by activating the extracellular regulated protein kinase (ERK) signaling pathway. Our data suggest that membrane potential changes play pivotal roles in regulating the proliferation, self-renewal and initiation of differentiation of mESCs.
\end{abstract}

Keywords: Optogenetic, Mouse embryonic stem cell, Proliferation, Self-renewal, Differentiation

\section{Introduction}

Mouse embryonic stem cells (mESCs) derived from the inner cell mass of blastocysts are considered multipluripotent with the characteristic of rapid self-renewal [1]. MESCs have been widely used to study embryonic development in vitro [2]. Clarifying the mechanisms for maintaining the ESC state or differentiation is beneficial for clinical applications. As far as we know, transcription factors (TFs) such as Oct4, Sox2, and Nanog form an autoregulatory network and act together to activate genes that maintain the pluripotent state and to silence genes for lineage-specific differentiation [3-7]. Many extracellular factors have been identified that trigger the transition of ESCs from self-renewal to differentiation by affecting the core TFs. However, the signaling pathways involved in this process require further investigation.

Ion channels contribute to the properties of cell membranes and play important roles in excitable as well as nonexcitable cells. Many factors can modulate the state

\footnotetext{
${ }^{*}$ Correspondence: peng63088@163.com

1 Department of Ophthalmology, General Hospital of Chinese People's

Liberation Army, Beijing 100853, China

Full list of author information is available at the end of the article
}

of cell stemness by altering membrane properties. A previous study demonstrated that ESCs possess outward $\mathrm{Kv}$ currents, and when the $\mathrm{K}^{+}$channels were blocked by TEA, mESC proliferation was significantly inhibited in a dose-dependent manner [8]. Furthermore, when the cell cycle was activated at $G_{0}$ and progressed from $G_{0}$ to $S$ phase, the membrane potential changed regularly. Notably, membrane depolarization was able to modulate the proliferation process in dividing cells [9-11].

Optogenetics is a powerful technology that applies light and genetics to manipulate and monitor the activities of defined cell populations. Optogenetics has enabled great advancements in neuroscience [12, 13], and it has been utilized to examine the functional integration of neurons differentiated from ESCs in vivo by introducing the light-gated channelrhodopsin-2 (ChR2) into mESCs $[14,15]$. Moreover, ChR2 has been found to enhance the differentiation of mESCs upon treatment with retinoic acid (RA), but the underlying mechanism is not clear [16]. The stem cell-based optogenetics approach provides an important tool for modulating the physiological state of stem cells. Thus, we examined whether the change in ion flux induced by blue light could modulate the ChR2-engineered-mESC fate from self-renewal to 
differentiation via the disruption of core TFs through the ERK signaling pathway.

\section{Materials and methods mESCs culture}

V6.5 ESCs (derived from the F1 hybrid of 129SvJae/ C57BL/6) were cultured on the dishes coated with $0.1 \%$ gelatin (Millipore, USA). The culture medium was prepared as preciously described [17].

\section{Creation of the ChR2-GFP-V6.5 ESC line}

Lentiviruses containing the ChR2-green fluorescent protein (GFP) were packaged as previously, and the promoter ubiquitin $\mathrm{C}$ ( $\mathrm{UbC}$ ) controlled the expression of ChR2-GFP [18]. Viruses were concentrated and redissolved in phosphate-buffered saline (PBS). V6.5 ESCs cells were infected with the lentivirus $(\mathrm{MOI}=5)$ with the addition of $5 \mu \mathrm{g} / \mathrm{ml}$ polybrene to enhance efficiency, followed by incubation for $6 \mathrm{~h}$. After 1 week, the transduction efficiency was assayed via fluorescence microscopy. To obtain homogenous ChR2-GFP-V6.5 ESCs, cells were sorted via fluorescence activated cell sorting (FACS), and the top 5\% of GFP-expressing cells were collected, and seeded one cell per-well in the 96-well plate. Subsequently, we harvested 13 colonies of the mESCs.

\section{Cell proliferation assay}

A total of $1 * 10^{5}$ ChR2-GFP-V6.5 ESCs and noninfected V6.5 ESCs were seeded in a $35 \mathrm{~mm}$ dish coated with $0.1 \%$ gelatin. The cells in each dish were counted with a Coulter counter (Beckman Coulter, USA) after 2 days. Cells treated without optical stimulation and V6.5 ESCs were used as controls. The cell proliferation rate of both groups was calculated. The quantities of viable and nonviable cells were measured using the trypan blue exclusion assay.

\section{Immunostaining of cultured cell}

ChR2-GFP-V6.5 ESCs seeded on Menzel-glass coverslips were fixed by $4 \%$ paraformaldehyde for $30 \mathrm{~min}$ and washed three times with PBS (5 min per wash). Then, the cells were permeabilized with $0.3 \%$ Triton and blocked with $10 \%$ bovine serum albumin (BSA) at $37{ }^{\circ} \mathrm{C}$ for $60 \mathrm{~min}$ and then covered with primary antibody solution and transferred to a cold room at $4{ }^{\circ} \mathrm{C}$ overnight. The cells were washed three times, and secondary goat antimouse antibody conjugated to Alexa Fluor 555 (Molecular Probe, USA) was added for incubation at $37{ }^{\circ} \mathrm{C}$ for $60 \mathrm{~min}$. After the cells were washed three times with PBS, 4',6-diamidino-2-phenylindole (DAPI) was added for $10 \mathrm{~min}$, and the cells were washed in water three times and mounted using Fluoromount (Dako, Denmark). The primary antibodies were mouse anti-OCT4 (Chemicon,
1:200), Rabbit-anti SOX2 (Abcam, 1:200), Rabbit-anti NANOG (Abcam, 1:200), Mouse-anti Ki67 (Abcam, 1:200) and mouse anti-SSEA1 (Chemicon, 1:200). The images were acquired with a Leica TCS SP2 inverted confocal microscopy system with an HCX PL APO CS 40× 1.25 NA oil immersion objective (Leica, USA). Immunostaining semi-quantification between non-light and light stimulation groups was done as previous [19].

\section{Teratoma assay}

For teratoma generation, the V6.5 ESCs or ChR2-GFPV6.5 ESCs $\left(5^{*} 10^{6}\right)$ were injected subcutaneously into nude mice. The nude mice were fed and housed under a 12-h light-dark cycle. The animal protocol was approved by the Institutional Animal Care and Use Committee of the General Hospital of Chinese People's Liberation Army and the Academy of Military Medical Sciences in accordance with the National Institutes of Health Guidelines for the Care and Use of Laboratory Animals. One group of mice was treated with optical stimulation at the injection sites every day (detailed in the optogenetic control section), while another group served as a nonphotoactivated control. After 30 days, tumors were harvested. Then, the size and weight of the teratomas from the photoactivated group were compared to those from the nonphotoactivated control group. All tissues were fixed in $10 \%$ formalin and embedded in paraffin, sections were stained with hematoxylin and eosin.

\section{Quantitative real-time PCR (qRT-PCR)}

mRNA was extracted from ChR2-GFP-V6.5 mESCs with TRIzol on ice (Invitrogen, USA). First-strand cDNA synthesis was performed using the Thermo Script ${ }^{\mathrm{TM}}$ RTPCR System (Invitrogen, USA). The mRNA level of each gene in both the photoactivated and nonphotoactivated control groups was determined by normalization to the Gapdh mRNA level. Real time-PCR was performed using SYBR Green Master Mix (Bio-Rad, USA) with a Bio-Rad system (Bio-Rad, USA) following the manufacturer's instructions. The real-time PCR program was performed as follows: 40 cycles of denaturation at $95{ }^{\circ} \mathrm{C}$ for $10 \mathrm{~s}$, annealing for $30 \mathrm{~s}$, and elongation at $56-60{ }^{\circ} \mathrm{C}$ for $30 \mathrm{~s}$. Nonspecific amplicons that appeared were evaluated by melting curves. All the primers corresponding to the examined genes are listed in Table 1.

\section{Cell-cycle and apoptosis analysis}

mESCs were trypsinized and fixed by $70 \%$ ice-cold ethanol. RNase A $(25 \mathrm{mg} / \mathrm{ml})$ was used to treat cells for $30 \mathrm{~min}$ at $37{ }^{\circ} \mathrm{C}$ to eliminate RNA. Cells were stained with $50 \mathrm{mg} / \mathrm{ml}$ propidium iodide for $10 \mathrm{~min}$ at room temperature load to FACSCalibur flow cytometer (BD Biosciences) to analysis cell cycle. Data acquisition was 
Table 1 Mouse qRT-PCR primer sets

\begin{tabular}{lll}
\hline Gene & Forward sequence & Reverse sequence \\
\hline Oct4 & GTGGAGGAAGCCGACAACAATGA & CAAGCTGATTGGCGATGTGAG \\
Sox2 & CAGGAGACCCCAAGATGCACAA & AATCCGGGGCTCCTTCATGTG \\
Esrrb & CAGGCAAGGATGACAGACG & GAGACAGCACGAAGGACTGC \\
Klf4 & GTGCAGCTTGCAGCAGTAAC & AGCGAGTTGGAAGGATAAAGTC \\
Nanog & TGGTCCCACAGTTGCCTAGTTC AGGTCTTCAGAGGAAGGGGA \\
Cdx2 & AGGCTGAGCCATGAGGAGTA & CAGAGTCCATAATTCCACTCA \\
Gata6 & CTCAGGGGTAGGGCATCA & GAGGACAGACTGACACCTATGTA \\
Foxa2 & CCCTACGCCAACATGAACTCG & GTTCTGCCGGTAGAAAGGGA \\
Fgf5 & CTGTATGGACCCACAGGGAGTAAC & ATTAAGCTCCTGGGTCGCAAG \\
Nestin & GCAGGGTCTACAGAGTCAGATCG & CAGCAGAGTCCTGTATGTAGCCA \\
Gata2 & GCCTGTGGCCTCTACTACAAGC & CCCTTTCTTGCTCTTCTTGGAT \\
Hand1 & AGGATGCACAAGCAGGTGA & GAGGCAGGAGGGAAGCTTT \\
Gachyury & GCTTCAAGGAGCTAACTAACGAG & CCAGCAAGAAAGAGTACATGGC \\
\hline
\end{tabular}

performed using CellQuest software (BD Pharmingen, USA), and the percentage of cells in the $G_{0} / G_{1}, S$, and $\mathrm{G}_{2} / \mathrm{M}$ phases was calculated using the Modfit. For analysis of apoptosis, each group of cells was washed with cold PBS, resuspended in $500 \mu$ l binding buffer, then transfer $100 \mu \mathrm{l}$ to the tube and added $5 \mu \mathrm{l}$ Annexin V-PE (Annexin V-PE apoptosis detection kit, BD Pharmingen, USA) and $5 \mu \mathrm{l} 7$-AAD, incubated in dark room at room temperature, subsequently added $400 \mu \mathrm{l}$ binding buffer to the tube. Finally, the cells were analyzed using the FACS Calibur flow cytometer.

\section{Colony-forming assay}

The colony-forming assay was performed by seeding 500 ChR2-GFP-V6.5 ESCs onto $35 \mathrm{~mm}$ dish and culturing with blue light, blue light + PD0325901, non-light, non-light + PD0325901 conditions, to form colony. After 7 days, cells were stained with Alkaline Phosphatase (AP) Detection Kit (Sigma-Aldrich, USA). AP-stained and differentiated colonies were counted to characterize the self-renewal ability of ChR2-GFP-V6.5 mESCs.

\section{Western blot analysis}

For western-blot, protein was collect by lysing the cells with RIPA buffer on ice for $30 \mathrm{~min}$. Then, $25 \mu \mathrm{g}$ of lysate was added to SDS-PAGE and transferred to PVDF membrane (Millipore, USA). Membrane were blocked with $10 \%$ non-fat milk in PBS with $0.01 \%$ Tween 20 (1 h, $37^{\circ} \mathrm{C}$ ), then incubated with the first antibody overnight at $4{ }^{\circ} \mathrm{C}$. First antibodies were used as the following dilutions: GAPDH (Abcam, USA) at 1:10,000, phosphoERK (Abcam, USA) at 1:1000 and total ERK (Abcam, USA) at 1:2000. Then, washed three times in PBS/0.01\%
Tween 20, followed by incubating in secondary antibody $\left(1 \mathrm{~h}, 37^{\circ} \mathrm{C}\right)$. After washing three times, protein bands in the PVDF membrane was detected using an enhanced chemiluminescence (ECL) substrate (Pierce, Thermo Fisher Scientific, USA), and protein bands were visualized via film exposure. GAPDH expression was used as an internal control. The protein expression level was determined by band density with Quantity One software (Bio-Rad, USA).

\section{Electrophysiology}

Whole-cell-patch clamp recording of cultured ChR2GFP-V6.5 ESCs was performed in a dark room at $26{ }^{\circ} \mathrm{C}$. ESCs were seeded onto Germany-glass coverslips in the dish. Cells were continuously perfused with external solution composed of (in mM) $145 \mathrm{NaCl}, 5 \mathrm{KCl}, 1.8 \mathrm{CaCl}_{2}, 1$ $\mathrm{MgCl}_{2}, 10$ HEPES and 10 glucose at $\mathrm{pH} 7.4$, and an osmolarity of $290-310 \mathrm{mOsm}$. The photoactivation-induced inward currents were recorded using an Axopatch 200B patch amplifier (Axon Instruments, USA) and digitized using a Digidata 1440 A/D converter and Clampex 10.0 software (Molecular Devices, USA). Borosilicate glass tubing was applied to prepare recording pipettes by using a horizontal puller (P-97, Sutter Instruments, USA); typically, the recording pipettes exhibited a resistance of 3.0-5.0 $\mathrm{M} \Omega$ when filled with pipette solution containing (in $\mathrm{mM}$ ) $140 \mathrm{KCl}, 10 \mathrm{EGTA}, 10$ HEPES and $5 \mathrm{MgATP}$ at $\mathrm{pH} 7.3$, and an osmolarity of 290-310 mOsm. After establishment of the whole-cell configuration, the adjustments to compensate for capacitance and series resistance were performed prior to recording the membrane signals. Between 70 and $80 \%$ of the series resistance was compensated electronically. Signals were filtered at $2 \mathrm{kHz}$ 
and digitized at $10 \mathrm{kHz}$. A leak subtraction protocol was performed. $470 \mathrm{~nm}$ blue light was delivered using a $40 \times$ water immersion microscope objective and a digitally operated shutter.

\section{Calcium imaging}

Calcium indicator Rhod-2 (Molecular probe, USA) were diluted into filtered recording buffer $(\mathrm{NaCl} 129 \mathrm{mM}$, $\mathrm{KCl} 4 \mathrm{mM}, \mathrm{MgCl}_{2} 1 \mathrm{mM}, \mathrm{CaCl}_{2} 2 \mathrm{mM}$, Glucose $10 \mathrm{mM}$, HEPES $10 \mathrm{mM}$ ) to obtain a loading solution with a final concentration in calcium indicator of $1 \mu \mathrm{g} / \mathrm{ml}$. The culture medium was replaced with loading solution and the cultures were incubated at room temperature for $20 \mathrm{~min}$ in the dark. The loading solution was then removed and replaced by fresh recording buffer, and the cultures were allowed to recover at $37{ }^{\circ} \mathrm{C}$ for $30 \mathrm{~min}$ in the dark before imaging. The cells were stimulated with blue light $(470 \mathrm{~nm})$ for $5 \mathrm{~min}$ (light intensity $10 \mathrm{~mW} / \mathrm{mm}^{2}$ ). We also added the $\mathrm{KCl}$ (5 $\mathrm{mM}$ final concentration) in recording buffer to induce the membrane depolarization and recording the calcium waves. In addition, for distinguishing the calcium source, we applied recording buffer without calcium. Images were acquired with a scanning confocal microscope (Leica, USA) and analyzed by ImageJ.

\section{Optogenetic control}

The cells were cultured in the room without light. Light stimulation was applied with a $470 \mathrm{~nm}$ light-emitting diode (LED) device (Thorlabs, USA). For whole-cell patch-clamp recording, a digitally controlled $470 \mathrm{~nm}$ LED light was projected to the back of a $40 \times$ water immersion microscope objective. The light intensity was modulated using a potentiometer and ranged from 0.1 to $10 \mathrm{~mW} / \mathrm{mm}^{2}$. The inward current peak was calculated for different light intensities. For optogenetic stimulation of cultured ChR2-GFP-V6.5 ESCs, optical stimulation was conducted in the incubator using the LED light source. All regions of the culture plate were stimulated with blue light $(470 \mathrm{~nm})$ for $5 \mathrm{~min} / \mathrm{h}(10 \mathrm{~ms}$ with $90 \mathrm{~ms}$ intervals and $10 \mathrm{~Hz}$ flickering light, $5 \mathrm{~min} / \mathrm{h}$ duration, light intensity $10 \mathrm{~mW} / \mathrm{mm}^{2}$ ). When the stimulation protocol was finished, the cells were fixed on the Menzel coverslips, and sister cells were prepared for immunostaining, qRT-PCR and cell counting. Additionally, we prepared cells exposed to different light intensities (low intensity: $0.1 \mathrm{~mW}$, medium intensity: $1 \mathrm{~mW}$, high intensity: $10 \mathrm{~mW}$ ) for Western blot analysis. For analyzing the role of ERK, we have added PD0325910 to the culture medium, then the cell underwent optical stimulation. For optical stimulation during teratoma assays, all of the animals were anesthetized ( $4 \%$ chloral hydrate) every day after cell injection at the same time, and we choose the same light intensity used for the cultured cells for the injected cells (10 Hz, $1 \mathrm{~h}$ duration, $10 \mathrm{~mW} / \mathrm{mm}^{2}$, beneath the skin at the injection site, actual value of $70 \mathrm{~mW} / \mathrm{mm}^{2}$ on the surface of the skin). The light stimulation was delivered by applying an LED light source to the injection site skin. Nonphotoactivated control animals were treated as described above without optical stimulation.

\section{Statistical analysis}

All data are presented as the mean \pm SD. Student's t-test was performed to compare the differences between groups. And the expression of ERK was analyzed by oneway analysis of variance (ANOVA). $\mathrm{P}<0.05$ was considered statistically significant.

\section{Results}

\section{Characterization of ChR2-GFP-V6.5 ESCs}

First, V6.5 ESCs were infected with a lentiviral ChR2GFP driver by the UbC promoter. On the basis of the expression level of GFP, the top 5\% cells were selected by FACS (Fig. 1a). The colony morphology and proliferation rate of the ChR2-GFP-V6.5 ESCs have no significant difference from those of nontransduced V6.5 mESCs (Fig. 1b, c) $(n=6, P>0.05$ vs. control). We found that the ChR2-GFP protein localized in the ESC membrane by using laser confocal scanning microscopy (Fig. 1d). Blue light $(470 \mathrm{~nm})$ generated inward photocurrents $(470 \mathrm{~nm}$, $2 \mathrm{~s}$ pulse duration) in an intensity-dependent manner in ChR2-GFP-V6.5 ESCs, while the steady-state photocurrents showed little inactivation (Fig. 1e). Therefore, the inward currents induced by blue light led to membrane depolarization. ChR2-GFP-V6.5 ESCs expressed the ESC markers OCT4 and SSEA-1, as indicated by immunostaining (Fig. 2a), and the core TFs, including Oct4, Sox2, Nanog, Esrrb and Klf4, as measured via qRTPCR (Fig. $2 b)(n=6, P>0.05$ vs. control), indicating that ChR2-GFP-V6.5 ESCs, just like noninfected cells, are in an undifferentiated state. Additionally, all of the ChR2GFP-V6.5 ESCs were positively stained for alkaline phosphatase (AP) (Fig. 2c). Teratomas were also detected after 30 days when the ChR2-GFP-V6.5 ESCs were subcutaneously injected into nude mice (Fig. 2d). And the teratomas between V6.5 ESCs and ChR2-GFP V6.5 ESCs has no obvious difference (Fig. 2e). Together, these results indicate that the introduction of ChR2 into V6.5 ESCs does not modulate the stemness of these cells.

\section{Optical stimulation inhibited the proliferation and disrupted the cell cycle progression of ChR2-GFP-V6.5 ESCs}

Subsequently, we examined whether blue light-induced membrane depolarization would affect the proliferation of ChR2-GFP-V6.5 ESCs. The application of blue light 

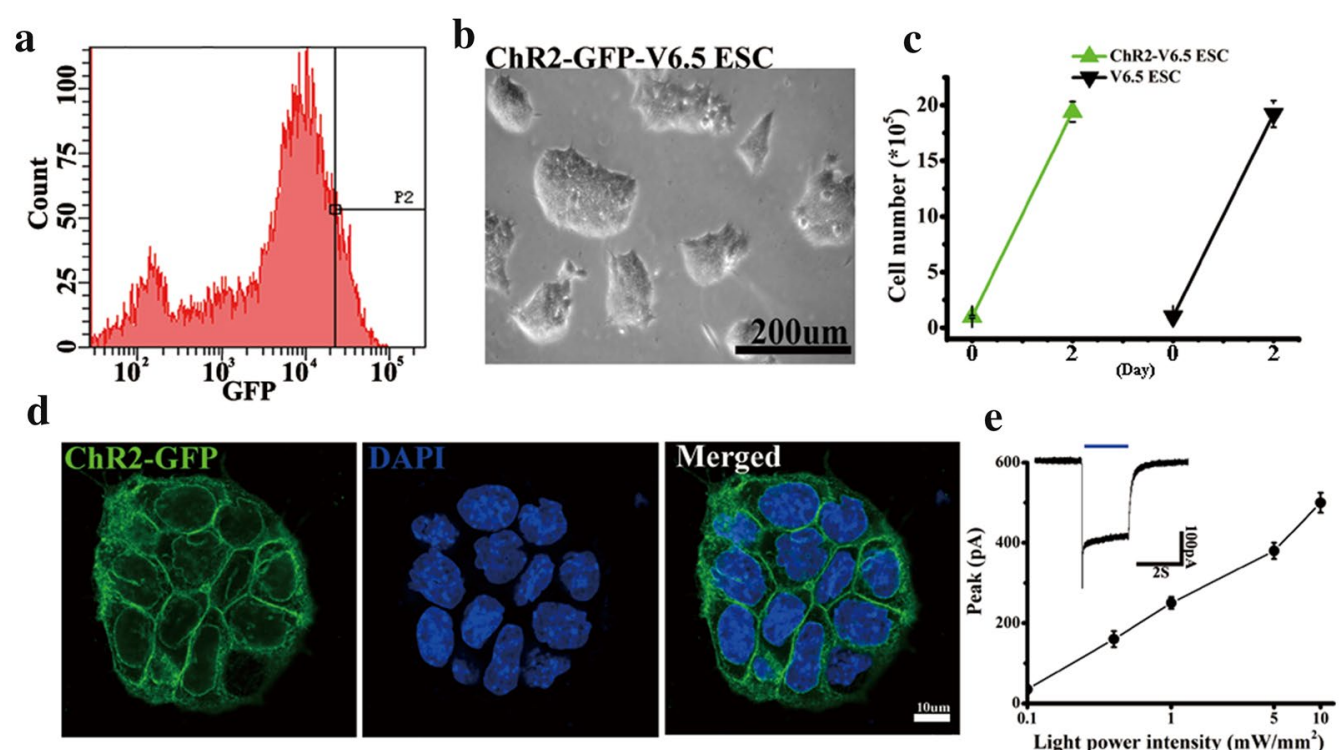

Fig. 1 Functional expression of ChR2 in V6.5 ESCs. a FACS sorting based on the GFP expression in the cell population. A gate for the 5\% of cells with the most fluorescence was selected. b Brightfield image of ChR2-GFP-V6.5 ESCs after FACS sorting. c Cell proliferation assay of V6.5 ESCs and ChR2-GFP-V6.5 ESCs. d Laser confocal scanning of ChR2-GFP-V6.5 ESCs revealing ChR2-GFP in the membrane. e Electrophysiological recording of light (wavelength of $470 \mathrm{~nm}$ ) of various intensities stimulating inward currents in ChR2-GFP-V6.5 ESCs (the blue bar represents the light stimulation). Inset, representative ChR2 photocurrents at a light intensity of $5 \mathrm{~mW}\left(\mathrm{n}=6,{ }^{*} \mathrm{P}<0.05\right.$ compared to the wild-type control)

stimulation for $48 \mathrm{~h}$ inhibited the proliferation of ChR2GFP-V6.5 ESCs, as indicated by the number of cells compared to that of control ESCs $(n=6, P<0.05$ vs. control), while optical stimulation had no impact on the proliferation of wild-type V6.5 ESCs (Fig. 3a) $(n=6, P>0.05$ vs. control). The ChR2-GFP-V6.5 ESCs were injected under the nude mouse skin, $470 \mathrm{~nm}$ blue light stimulation was performed every day. The size of teratomas was much smaller in $470 \mathrm{~nm}$ blue light stimulation group compared with that in the nonphotoactivated control group (Fig. 3b, c) $(\mathrm{n}=6, \mathrm{P}<0.05$ vs. control). Optical stimulation reduced the percentage of cells in the $S$ phase while increasing that in the $G_{2}$ phase (Fig. $3 d$ ). The proportion of cells in the $S$ phase decreased from $73.75 \pm 4 \%$ in the control group to $56.75 \pm 2.8 \%$ in the photoactivated group ( $\mathrm{n}=6, \mathrm{P}<0.05$ vs. control). The percentage of cells in the $G_{2}$ phase in the nonphotoactivated control group was $13.57 \pm 2.5 \%$, while photoactivation increased the percentage of cells in the $G_{2}$ phase to $23.57 \pm 2.9 \%(n=6$, $\mathrm{P}<0.05$ vs. control). The cell cycle characteristics of the photoactivated ChR2-GFP-V6.5 ESCs are summarized in Fig. 3e. The expression of Ki67 obviously decreased with blue light stimulation (Fig. 3f). Furthermore, to determine whether photoactivation could affect the viability of ChR2-GFP-V6.5 ESCs, we measured cell viability by the trypan blue assay. Photoactivation did not affect the viability of ChR2-GFP-V6.5 ESCs (Fig. 4a) (n=6, P>0.05 vs. control). We then used flow cytometry to measure the apoptosis rates of the photoactivated group and the nonphotoactivated control group, and no notable difference was found between these two groups (Fig. $4 b-d)(n=6$, P $>0.05$ vs. control).

\section{Optical stimulation inhibited the self-renewal of ChR2-GFP-V6.5 ESCs}

In addition to having a slower proliferation rate, photoactivated ChR2-GFP-V6.5 ESCs displayed flatter colony morphology than the nonphotoactivated control ChR2GFP-V6.5 ESCs (Fig. 5a). Because the core TFs are essential for ESC self-renewal, we measured the mRNA levels of Oct4, Sox2, Nanog, Esrrb and Klf4 by qRT-PCR. We found significant downregulation of these pluripotency markers in the cells of the photoactivated group compared to those of the nonphotoactivated group (Fig. 5b) ( $\mathrm{n}=6, \mathrm{P}<0.05$ vs. control). Moreover, the immunostaining has shown the decrease of OCT4 and SSEA-1 in the nonphotoactivated group [(Fig. 5e) $(\mathrm{n}=6, \mathrm{P}<0.05$ vs. control)]. To determine whether reduced core TF activity after optical stimulation is involved in the compromised self-renewal, we examined the ability of ChR2-GFP-V6.5 ESCs to form colonies upon optical stimulation. Single cells were seeded and treated with or without 7 days of 
a
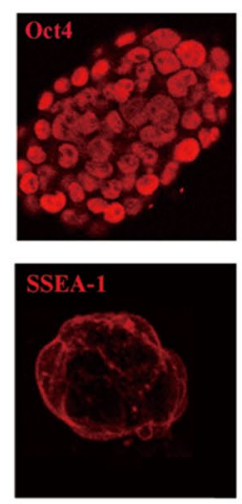

b
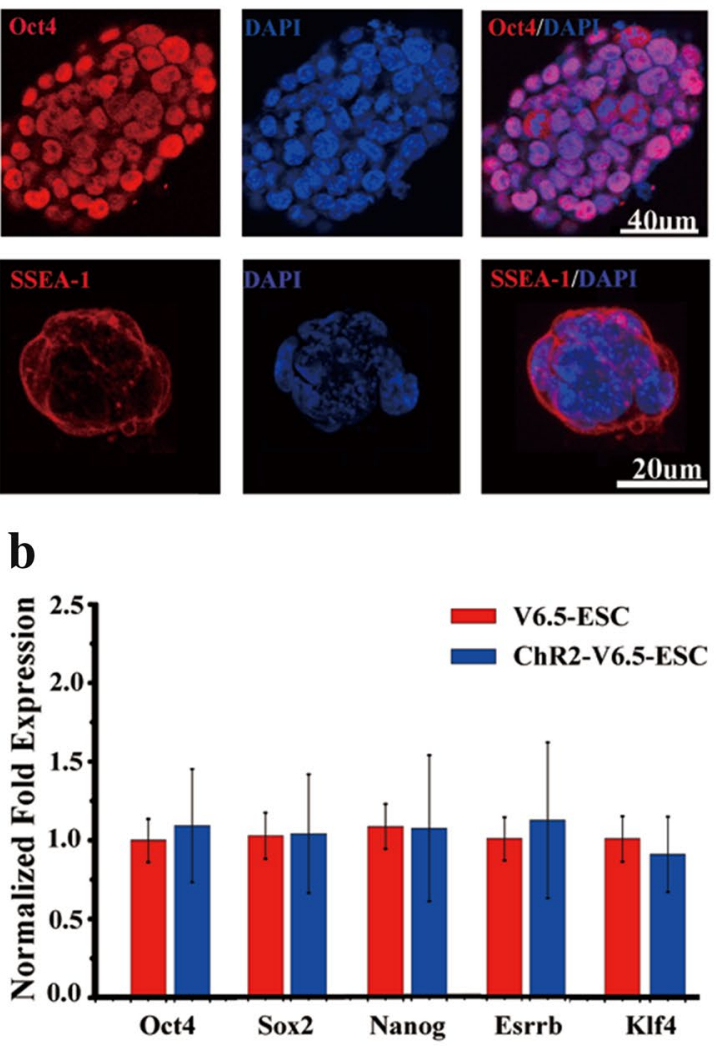

c

d

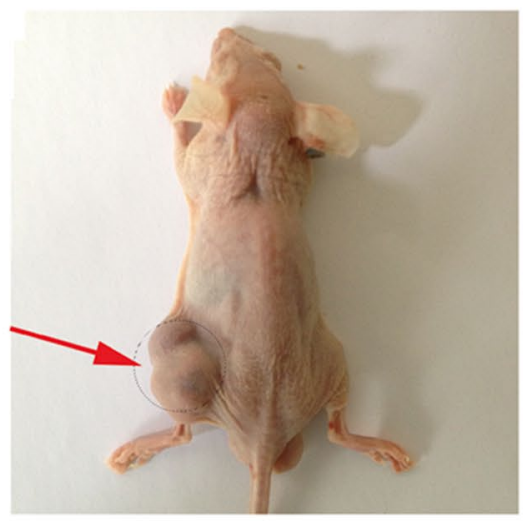

e

Ectoderm
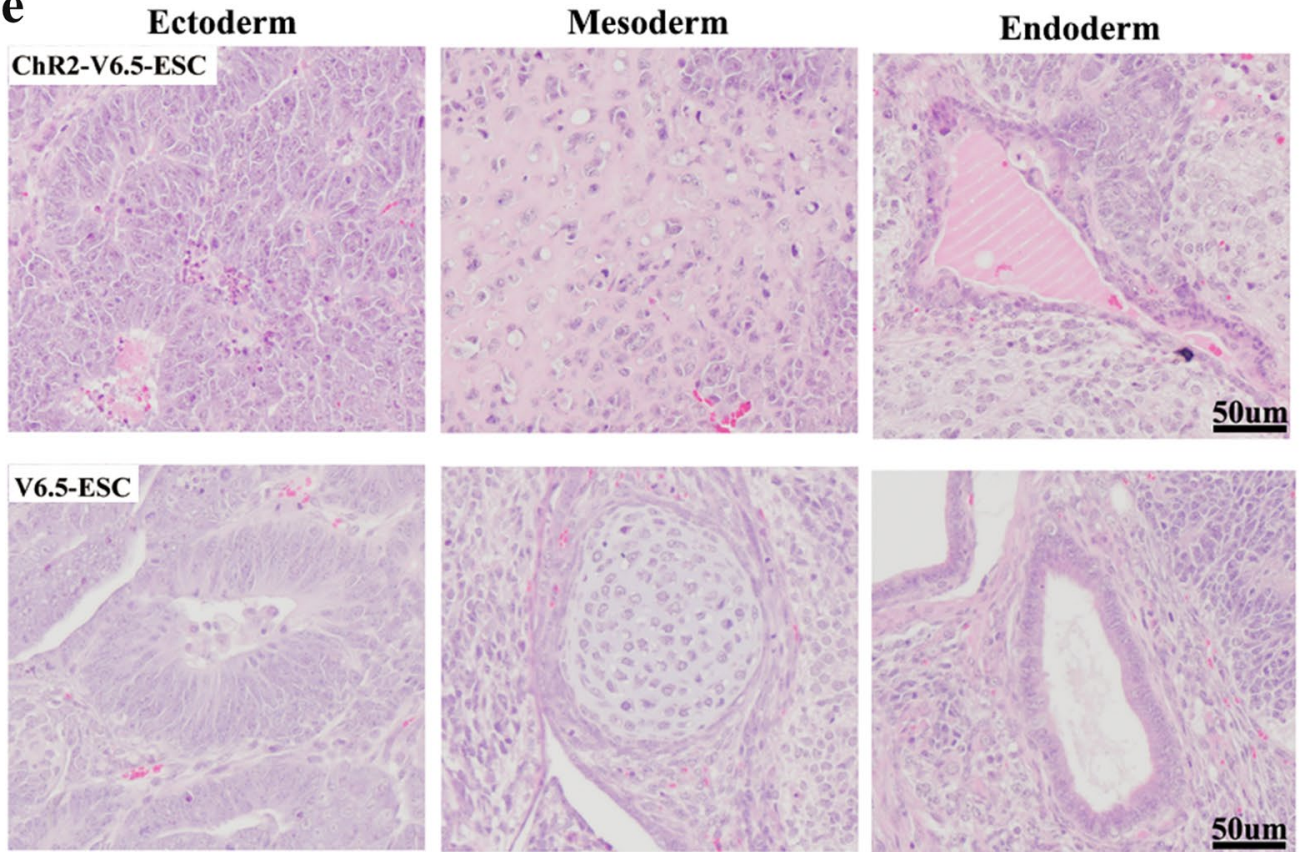

50um

Fig. 2 Characteristics of the ChR2-GFP-V6.5 ESCs. a Immunostaining for the pluripotency markers Oct4 and SSEA1 in ChR2-GFP-V6.5 ESCs. b qRT-PCR analysis of the pluripotency-associated genes Oct4, Sox2, Nanog, Esrrb and Klf4 in ChR2-GFP-V6.5 ESCs and V6.5 ESCs. c AP staining of ChR2-GFP-V6.5 ESCs. d A nude mouse subcutaneously injected with $5^{*} 10^{6}$ ChR2-GFP-V6.5 ESCs on the left side formed a teratoma. ( $n=6$, *P $<0.05$ compared to the wild-type control). e Hematoxylin and eosin staining of teratomas derived from V6.5 ESCs and ChR2-GFP-V6.5 ESCs 


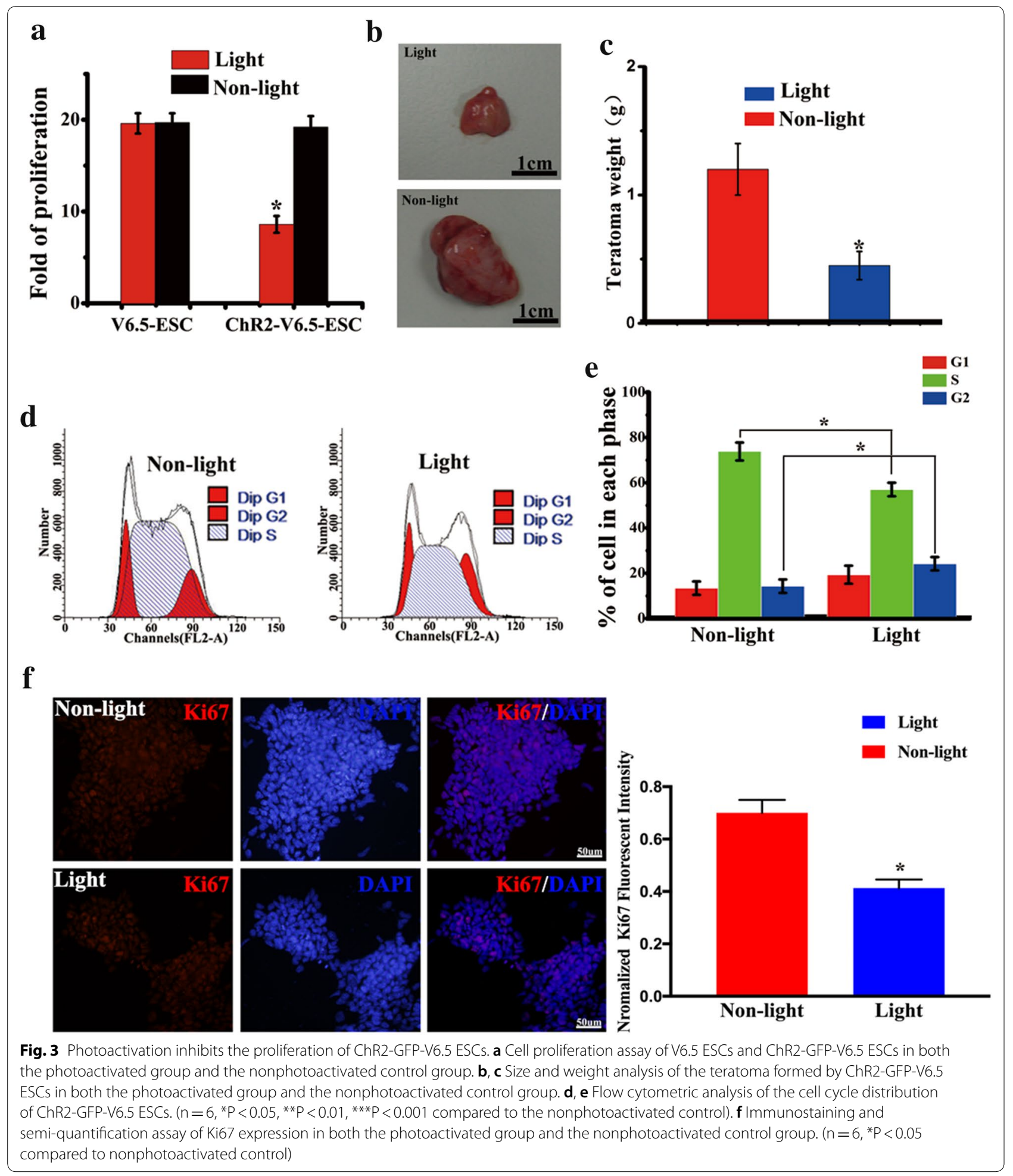

light exposure. The colonies formed from a single cell were stained for AP (Fig. 5c). ChR2-GFP-V6.5 ESCs without light exposure developed numerous AP-positive colonies, while photoactivation significantly reduced the number of AP-positive colonies (Fig. $5 \mathrm{~d})(\mathrm{n}=6, \mathrm{P}<0.05$ vs. control). 


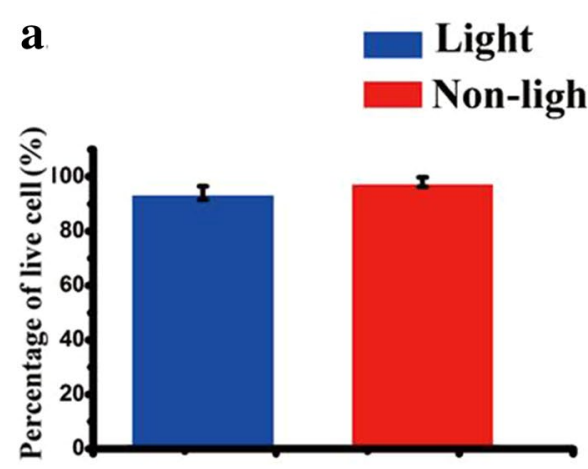

c

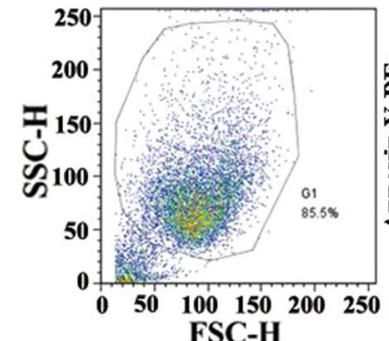

Light

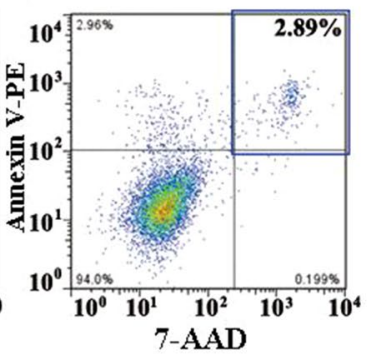

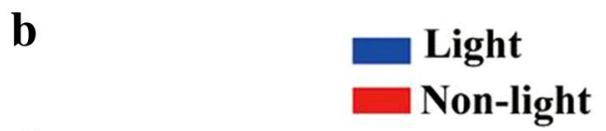

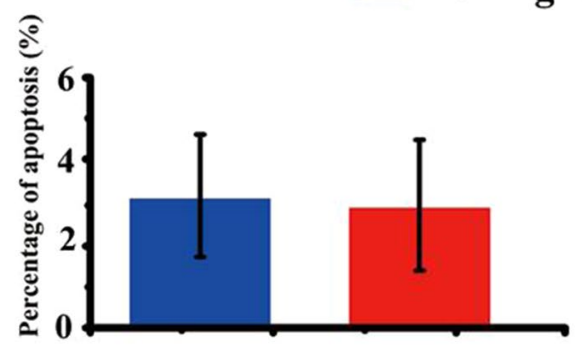

d

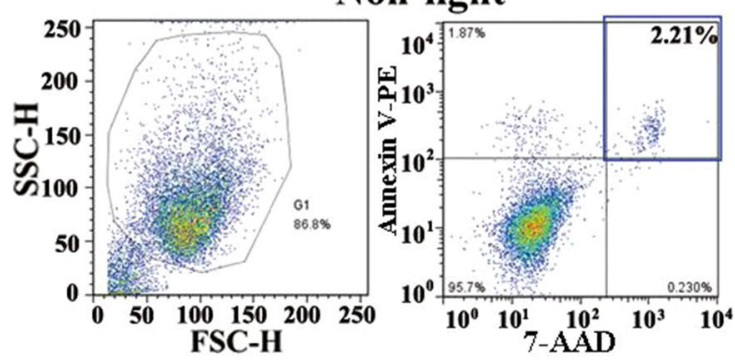

Fig. 4 Optical stimulation does not alter the viability of ChR2-GFP-V6.5 ESCs. a The results of the cell viability assay of ChR2-GFP-V6.5 ESCs (trypan blue exclusion assay) in both the photoactivated group and the nonphotoactivated control group are summarized in a bar graph. $\mathbf{b}$ Summary graph of the apoptosis of ChR2-GFP-V6.5 ESCs in both the photoactivated group and the nonphotoactivated control group. c, $\mathbf{d}$ Flow cytometry quantifying the apoptosis of ChR2-GFP-V6.5 ESCs in the nonphotoactivated and photoactivated groups. ( $n=6$, *P<0.05 compared to the nonphotoactivated control)

\section{Optical stimulation triggers the differentiation of ChR2-GFP-V6.5 ESCs via ERK activation}

The results above showed that photoactivation could substantially reduce the mRNA levels of TFs, including Oct4, Nanog, Sox2, Esrrb and Klf4. Moreover, teratomas derived from ChR2-GFP-V6.5 with photoactivated group largely appeared ectoderm structures, while endoderm was distinctly less than that of nonphotoactivated group (Fig. 6a). Next, to address whether blue light stimulation acts as a permissive signal to initiate ChR2-GFP-V6.5 ESC differentiation, we asked whether this stimulation could modulate the lineage by measuring the mRNA level of lineage-specific markers. Interestingly, photoactivation resulted in an increased mRNA level of various differentiation markers (including Branchyury, Hand1, Fgf5, Cdx2 and Nestin), especially markers of the trophectoderm and ectoderm fates (Cdx2, Fgf5 and Nestin) (Fig. 6b) $(\mathrm{n}=6, \mathrm{P}<0.05$ vs. control). ERK activation plays an important role in the initiation of ESC differentiation [20]. However, whether optical stimulation could affect intracellular ERK activity was unclear. Thus, we treated ChR2-GFP-V6.5 ESCs with different intensities of light stimulation for $48 \mathrm{~h}$ and analyzed the phosphorylation of ERK. Western blot analysis showed that after $48 \mathrm{~h}$ of photoactivation, the ERK activity was significantly upregulated as the light intensity increased (Fig. 6c, d) $(\mathrm{n}=6, \mathrm{P}<0.05$ vs. control). Furthermore, the MEK inhibitor PD0325901 could obviously rescue the down-regulated mRNA level and expression of core transcriptional factors OCT4, SSEA-1, SOX2 and NANOG in the photoactivated group partially (Fig. 6e, f) $(\mathrm{n}=6, \mathrm{P}<0.05$ vs. control). The application partially rescue the colony-form ability of ChR2-GFP V6.5 ESCs inhibited by photoactivation (Fig. 6g). PD0325901 has no obvious effect on the nonphotoactivated group (Fig. $6 \mathrm{e}-\mathrm{g})(\mathrm{n}=6, \mathrm{P}<0.05$ vs. control). Furthermore, we have observed the calcium wave in the ChR2-GFP-V6.5 ESCs. We found the slow calcium wave without light stimulation, and the light stimulation could obviously elevate the calcium activity of ChR2-GFP-V6.5 ESCs. We also observed the calcium activity induced by $\mathrm{KCl}$, which could induce membrane depolarization. Moreover, after elimination the extra-cellular calcium, we could still observe the light induced calcium activity (Fig. 6h). 
a
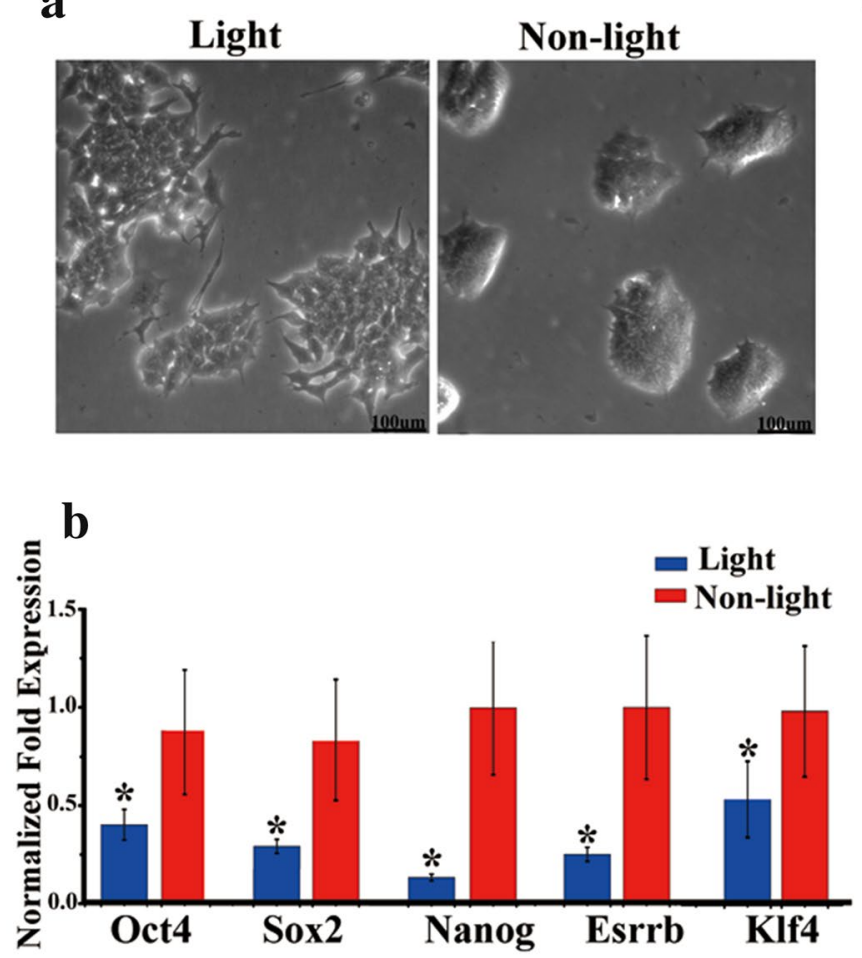

c
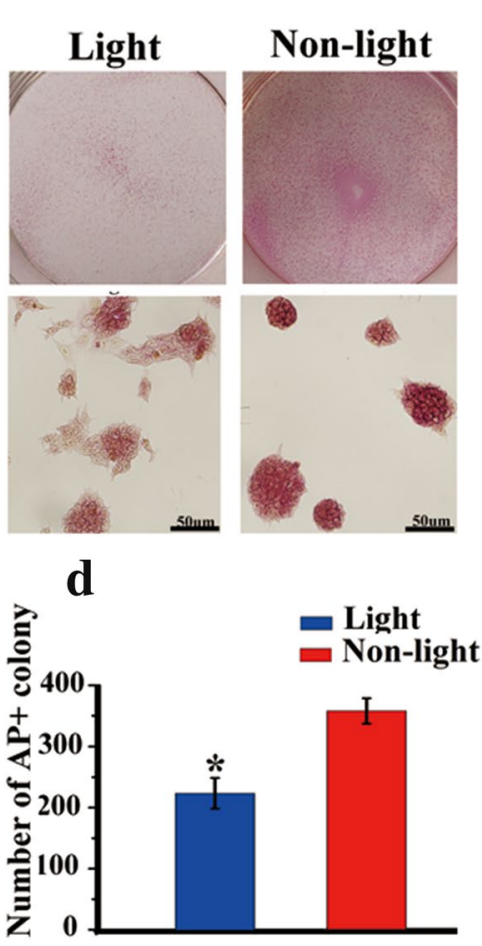

e
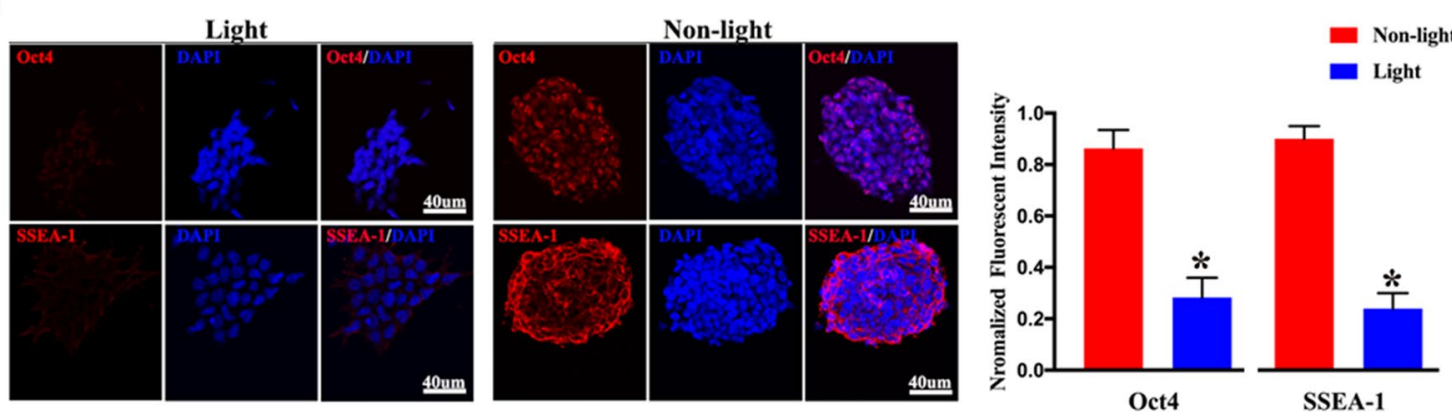

Fig. 5 Photoactivation inhibits the self-renewal of ChR2-GFP-V6.5 ESCs. a Brightfield image of photoactivated and nonphotoactivated ChR2-GFP-V6.5 ESCs. b qRT-PCR analysis of the TFs Oct4, Sox2, Nanog, Esrrb and KIf4 in photoactivated and nonphotoactivated ChR2-GFP-V6.5 ESCs. c Colony formation assay of photoactivated and nonphotoactivated ChR2-GFP-V6.5 ESCs. d Statistical analysis of the colony formation data of photoactivated and nonphotoactivated ChR2-GFP-V6.5 ESCs. e Immunostaining and semi-quantification for the pluripotency markers OCT4 and SSEA-1 in photoactivated and nonphotoactivated ChR2-GFP-V6.5 ESCS. $\left(n=6,{ }^{* * *} \mathrm{P}<0.001\right.$ compared to the nonphotoactivated control)

\section{Discussion}

In our present work, by applying optogenetics, we found that optical stimulation could not only inhibit the proliferation of ChR2-GFP-V6.5 ESCs but also induce the transition of ChR2-GFP-V6.5 ESCs from self-renewal to differentiation. Notably, we observed that optical stimulation enhanced the activation of the ERK signaling pathway, which is important for controlling mESC fate.

Optogenetics offers biologists a new way to stimulate cells [21]. ChR2 has been extensively used to explore neural circuits because it provides precise temporal and spatial information while being noninvasive [22, 23]. Interestingly, utilizing light to control signaling pathways is an attractive approach in cell biology, as low intensity light can activate cells with temporal precision and no damage [24]. ESCs hold great promise for regenerative medicine as these cells can indefinitely propagate and generate any of the specialized cell types [25]. In addition, ESCs can be used to study the development and function of human tissues [26]. The stemness state is controlled by the core TFs including Oct4, Sox2, and Nanog [6, 27-30], and ESC differentiation involves inhibition of the core 


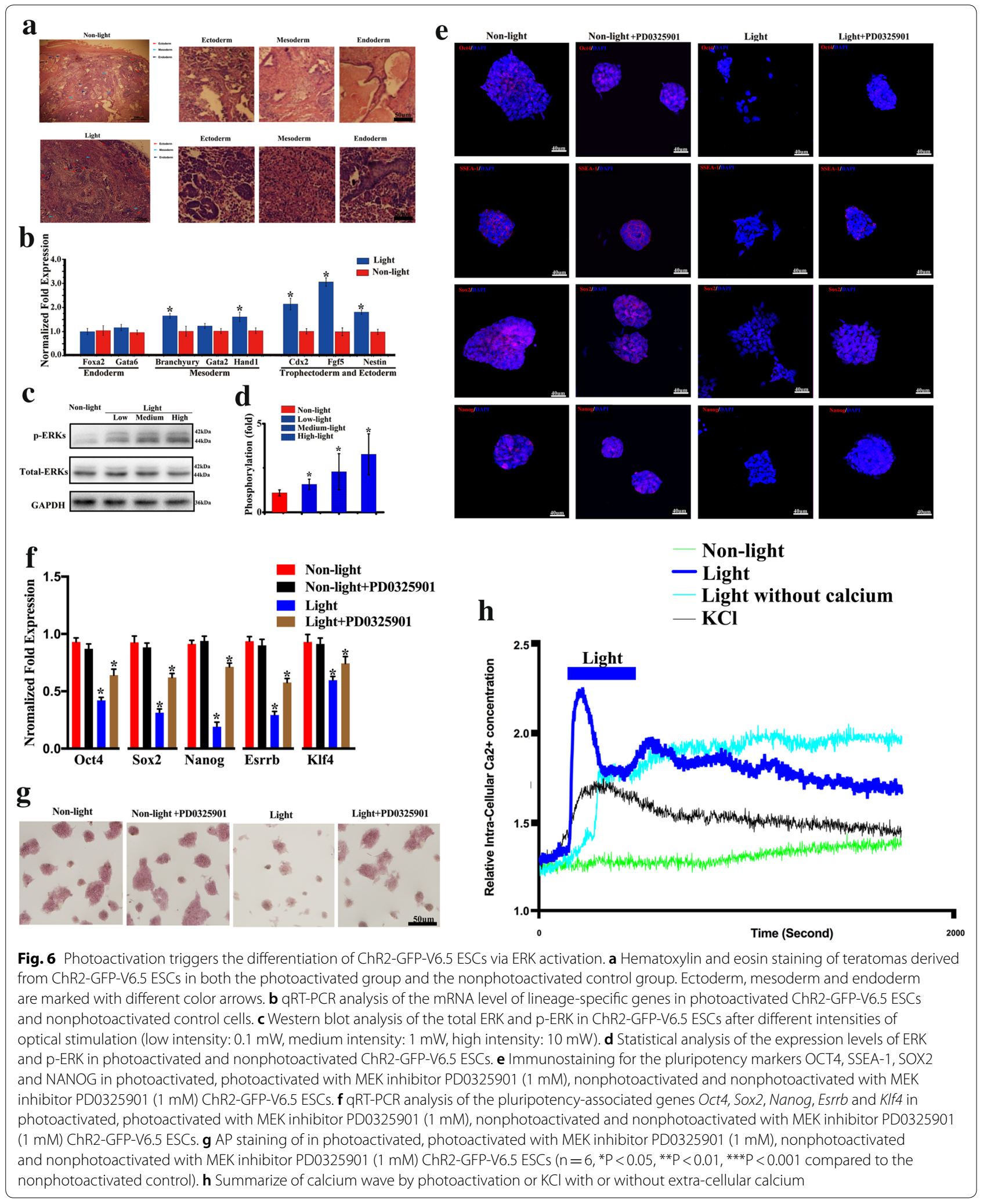


TFs, resulting in the activation of lineage-specific genes $[31,32]$. However, the intrinsic mechanism controlling the pluripotent state and initiation of differentiation needs more study [33]. Many signaling pathways involved in $\mathrm{mESC}$ self-renewal and differentiation have been identified by applying agonists and antagonists. However, methods facilitating the precise control of cell signaling have also been intensely explored [34].

mESCs expressing ChR2 were used to analyze the integration of grafted neurons at synaptic level in the neural system in vitro [14-16]. We chose a much higher light density ( $5 \mathrm{~min} / \mathrm{h}, 10 \mathrm{~mW} / \mathrm{mm}^{2}$ ) to stimulate the $\mathrm{mESCs}$. Under these conditions, we found that optical stimulation-induced depolarization inhibited ChR2-GFP-V6.5 ESC proliferation and self-renewal and initiated the differentiation of ChR2-GFP-V6.5 ESCs without affecting the cell viability. Changes in membrane potential could affect the fate decision of ESCs, as the membrane became hyperpolarized when the ESC cell cycle progressed from the $G_{1}$ to the $S$ phase but became depolarized when the ESCs started to differentiate [35]. When the $\mathrm{K}^{+}$channel expressed on ESCs was blocked, the proliferation and cell cycle progression of ESCs were significantly inhibited [8, 36]. RA, an agent that is essential for embryonic neural development, could enhance differentiation by inducing membrane depolarization [37], and an endogenous RA gradient has been detected during embryonic development via a live imaging method [38]. In our study, after optical stimulation, the proliferation rate of mESCs was reduced, and the cell cycle was inhibited. As ChR2 channels that are opened by blue light exposure depolarize the cell [23,39], it is possible that the normal membrane potential oscillations of mESCs were disrupted by light stimulation, leading to differentiation of the mESCs. However, light stimulation on mESC did not lead to differentiation to a specific lineage.

We detected activation of the ERK signaling pathway, which is involved in the inhibition of ChR2-GFP-V6.5 ESC proliferation and initiation of ChR2-GFP-V6.5 ESC differentiation, after optical stimulation, and the activation occurred in a light intensity-dependent manner. ERK activity could regulate ESC self-renewal and fate determination [40, 41]. Inhibition of ERK activity promotes mESC self-renewal by regulating core TFs, such as Nanog [29, 42-44]. Moreover, the differentiation of ESCs could be blocked by an ERK inhibitor [45], and glycogen synthase kinase 3 (GSK3) could maintain mESC long-term pluripotency without Leukemia inhibitory factor (LIF) [41, 46]. Bone morphogenetic protein (BMP) controls the ESC fate decision by tuning ERK activity through DUSP9 [47]. Furthermore, activation of ERK triggered the transition of ESCs from self-renewal to differentiation [20]. The FGF/MEK/ERK pathway is essential for trophectoderm and primitive endoderm formation in murine embryonic development [44, 48-50]. The ERK signaling pathway regulates neuroectoderm specification via the regulation of Poly (ADP-ribose) polymerase 1 (PARP-1) activity in mESCs [51-53].

Therefore, in our study, the differentiation of ChR2GFP-V6.5 ESCs after optical stimulation might occur due to the activation of the ERK signaling pathway. However, the MEK inhibitor PD0325901 could partially rescue the down-regulated expression of core transcriptional factors induced by optical stimulation. Many extracellular factors could affect the stem cell state [54]. Thus, we do not rule out a potential role of other signaling pathways in the ChR2-GFP-V6.5 ESC differentiation induced by photoactivation. For instance, similar to ERK signaling, the calcineurin-NFAT-Src pathway triggers mESC differentiation. These two distinct signaling pathways might cooperate to control mESC fate [55]. Previous studies have also found that optical stimulation could induce an influx of $\mathrm{Ca}^{2+}$ into the cytoplasm [56]. Intracellular $\mathrm{Ca}^{2+}$ regulates the proliferation, apoptosis and differentiation of cells through activating downstream pathways [57]. We have observed the increase of intra-cellular calcium concentration after $470 \mathrm{~nm}$ light stimulation. In future studies, we will put particular emphasis on the role of $\mathrm{Ca}^{2+}$ and its downstream signaling pathways in the initiation of differentiation after photoactivation. Further study might provide a new understanding of the initiation of the differentiation of ChR2-GFP-V6.5 ESCs after photoactivation.

In conclusion, by utilizing optogenetic techniques, we have demonstrated that cell membrane depolarization plays an important role in modulating the proliferation, self-renewal and initiation of differentiation of mESCs. Our results demonstrate that the activation of ERK is involved in the transition of mESCs from selfrenewal to differentiation that is induced by membrane depolarization.

\section{Acknowledgements}

This research was supported by Grants from National Key Research and Development Program (2018YFA0107303), National Natural Science Foundation of China (NSFC 81501090), and National Key Basic Research Program of China (973 Project 2013CB967001).

\section{Authors' contributions}

SW and LD contributed to the conception and design, data collection and analysis, as well as writing and revision of the manuscript. GP contributed to the conception and design, data analysis and interpretation, and revision of the manuscript. All authors reviewed the manuscript. All authors read and approved the final manuscript.

\section{Funding}

This research was supported by Grants from National Key Research and Development Program (2018YFA0107303), National Natural Science Foundation of China (NSFC 81501090), and National Key Basic Research Program of China (973 Project 2013CB967001). 


\section{Ethics approval and consent to participate}

The animal protocol was approved by the Institutional Animal Care and Use Committee of the General Hospital of Chinese People's Liberation Army and the Academy of Military Medical Sciences in accordance with the National Institutes of Health Guidelines for the Care and Use of Laboratory Animals. No patient was involved.

\section{Consent for publication}

Informed consent for publication was obtained from all participants.

\section{Competing interests}

The authors declare that they have no competing interests.

\begin{abstract}
Author details
${ }^{1}$ Department of Ophthalmology, General Hospital of Chinese People's Liberation Army, Beijing 100853, China. ${ }^{2}$ Department of Ophthalmology, Affiliated Hospital of Academy of Military Medical Sciences, Beijing 100071, China. ${ }^{3}$ Department of Pathophysiology, Basic Medical College, Zhengzhou University, Zhengzhou 450052, Henan, China.
\end{abstract}

Received: 11 February 2019 Accepted: 21 August 2019

Published online: 03 September 2019

\section{References}

1. Evans MJ, Kaufman MH. Establishment in culture of pluripotential cells from mouse embryos. Nature. 1981;292(5819):154-6.

2. Murry CE, Keller G. Differentiation of embryonic stem cells to clinically relevant populations: lessons from embryonic development. Cell. 2008;132(4):661-80.

3. Boyer LA, Lee TI, Cole MF, Johnstone SE, Levine SS, Zucker JP, et al. Core transcriptional regulatory circuitry in human embryonic stem cells. Cell. 2005;122(6):947-56.

4. Chen X, Xu H, Yuan P, Fang F, Huss M, Vega VB, et al. Integration of external signaling pathways with the core transcriptional network in embryonic stem cells. Cell. 2008;133(6):1106-17.

5. Kim J, Chu J, Shen X, Wang J, Orkin SH. An extended transcriptional network for pluripotency of embryonic stem cells. Cell. 2008;132(6):1049-61.

6. Young RA. Control of the embryonic stem cell state. Cell. 2011;144(6):940-54

7. Boiani M, Schöler HR. Regulatory networks in embryo-derived pluripotent stem cells. Nat Rev Mol Cell Biol. 2005;6(11):872-81.

8. Wang K, Xue T, Tsang SY, Van Huizen R, Wong CW, Lai KW, et al. Electrophysiological properties of pluripotent human and mouse embryonic stem cells. Stem Cells. 2005;23(10):1526-34.

9. Sundelacruz S, Levin M, Kaplan DL. Role of membrane potential in the regulation of cell proliferation and differentiation. Stem Cell Rev. 2009;5(3):231-46

10. Momose-Sato Y, Sato K, Kinoshita M. Spontaneous depolarization waves of multiple origins in the embryonic rat CNS. Eur J Neurosci. 2007;25(4):929-44.

11. Wang DD, Krueger DD, Bordey A. GABA depolarizes neuronal progenitors of the postnatal subventricular zone via GABAA receptor activation. J Physiol. 2003;550(Pt 3):785-800.

12. Deisseroth K. Optogenetics. Nat Methods. 2010;8(1):26-9.

13. Fenno $L$, Yizhar $O$, Deisseroth $K$. The development and application of optogenetics. Annu Rev Neurosci. 2011;34:389-412.

14. Weick JP, Johnson MA, Skroch SP, Williams JC, Deisseroth K, Zhang SC. Functional control of transplantable human ESC-derived neurons via optogenetic targeting. Stem Cells. 2010;28(11):2008-16.

15. Tonnesen J, Parish CL, Sorensen AT, Andersson A, Lundberg C, Deisseroth $K$, et al. Functional integration of grafted neural stem cell-derived dopaminergic neurons monitored by optogenetics in an in vitro Parkinson model. PLOS ONE. 2011;6(3):e17560.

16. Stroh A, Tsai HC, Wang LP, Zhang F, Kressel J, Aravanis A, et al. Tracking stem cell differentiation in the setting of automated optogenetic stimulation. Stem Cells. 2011;29(1):78-88.

17. Jia J, Zheng X, Hu G, Cui K, Zhang J, Zhang A, et al. Regulation of pluripotency and self-renewal of ESCs through epigenetic-threshold modulation and mRNA pruning. Cell. 2012;151(3):576-89.
18. Boyden ES, Zhang F, Bamberg E, Nagel G, Deisseroth K. Millisecondtimescale, genetically targeted optical control of neural activity. Nat Neurosci. 2005;8(9):1263-8

19. Wang SJ, Zhang C, You Y, Shi CM. Overexpression of RNA helicase p68 protein in cutaneous squamous cell carcinoma. Clin Exp Dermatol. 2012;37(8):882-8.

20. Kunath T, Saba-El-Leil MK, Almousailleakh M, Wray J, Meloche S, Smith A. FGF stimulation of the Erk1/2 signalling cascade triggers transition of pluripotent embryonic stem cells from self-renewal to lineage commitment. Development. 2007;134(16):2895-902.

21. Toettcher JE, Voigt CA, Weiner OD, Lim WA. The promise of optogenetics in cell biology: interrogating molecular circuits in space and time. Nat Methods. 2011:8(1):35-8.

22. Nagel G, Szellas T, Kateriya S, Adeishvili N, Hegemann P, Bamberg E. Channelrhodopsins: directly light-gated cation channels. Biochem Soc Trans. 2005:33(Pt 4):863-6.

23. Nagel G, Szellas T, Huhn W, Kateriya S, Adeishvili N, Berthold P, et al. Channelrhodopsin-2, a directly light-gated cation-selective membrane channel. Proc Natl Acad Sci USA. 2003;100(24):13940-5.

24. Gorostiza P, Isacoff EY. Optical switches for remote and noninvasive control of cell signaling. Science. 2008;322(5900):395-9.

25. Sasai $Y$. Next-generation regenerative medicine: organogenesis from stem cells in 3D culture. Cell Stem Cell. 2013;12(5):520-30.

26. Stergachis Andrew B, Neph S, Reynolds A, Humbert R, Miller B, Paige Sharon L, et al. Developmental fate and cellular maturity encoded in human regulatory DNA landscapes. Cell. 2013;154(4):888-903.

27. Chambers I, Silva J, Colby D, Nichols J, Nijmeijer B, Robertson M, et al. Nanog safeguards pluripotency and mediates germline development. Nature. 2007;450(7173):1230-4

28. Chambers I, Smith A. Self-renewal of teratocarcinoma and embryonic stem cells. Oncogene. 2004:23(43):7150-60.

29. Niwa H, Ogawa K, Shimosato D, Adachi K. A parallel circuit of LIF signalling pathways maintains pluripotency of mouse ES cells. Nature. 2009;460(7251):118-22.

30. Silva J, Nichols J, Theunissen TW, Guo G, van Oosten AL, Barrandon $\mathrm{O}$, et al. Nanog is the gateway to the pluripotent ground state. Cell. 2009;138(4):722-37.

31. Xu N, Papagiannakopoulos T, Pan G, Thomson JA, Kosik KS. MicroRNA-145 regulates OCT4, SOX2, and KLF4 and represses pluripotency in human embryonic stem cells. Cell. 2009;137(4):647-58.

32. Martinez NJ, Gregory RI. MicroRNA gene regulatory pathways in the establishment and maintenance of ESC identity. Cell Stem Cell. 2010;7(1):31-5.

33. Tsuneyoshi N, Dunn N. Guards at the gate to embryonic stem cell differentiation. Cell. 2013;153(2):281-3.

34. Weijer CJ. Visualizing signals moving in cells. Science. 2003;300(5616):96-100.

35. Ng SY, Chin CH, Lau YT, Luo J, Wong CK, Bian ZX, et al. Role of voltagegated potassium channels in the fate determination of embryonic stem cells. J Cell Physiol. 2010;224(1):165-77.

36. Lau YT, Wong CK, Luo J, Leung LH, Tsang PF, Bian ZX, et al. Effects of hyperpolarization-activated cyclic nucleotide-gated (HCN) channel blockers on the proliferation and cell cycle progression of embryonic stem cells. Pflugers Arch. 2011;461(1):191-202.

37. Ghiani CA, Yuan X, Eisen AM, Knutson PL, DePinho RA, McBain CJ, et al. Voltage-activated $\mathrm{K}+$ channels and membrane depolarization regulate accumulation of the cyclin-dependent kinase inhibitors p27(Kip1) and p21(CIP1) in glial progenitor cells. J Neurosci. 1999;19(13):5380-92.

38. Shimozono S, limura T, Kitaguchi T, Higashijima SI, Miyawaki A. Visualization of an endogenous retinoic acid gradient across embryonic development. Nature. 2013;496(7445):363-6.

39. Bi A, Cui J, Ma YP, Olshevskaya E, Pu M, Dizhoor AM, et al. Ectopic expression of a microbial-type rhodopsin restores visual responses in mice with photoreceptor degeneration. Neuron. 2006;50(1):23-33.

40. Kolch W. Coordinating ERK/MAPK signalling through scaffolds and inhibitors. Nat Rev Mol Cell Biol. 2005;6(11):827-37.

41. Ying QL, Wray J, Nichols J, Batlle-Morera L, Doble B, Woodgett J, et al. The ground state of embryonic stem cell self-renewal. Nature. 2008;453(7194):519-23.

42. Lanner F, Lee KL, Sohl M, Holmborn K, Yang H, Wilbertz J, et al. Heparan sulfation-dependent fibroblast growth factor signaling maintains 
embryonic stem cells primed for differentiation in a heterogeneous state. Stem Cells. 2010;28(2):191-200.

43. Buehr M, Smith A. Genesis of embryonic stem cells. Philos Trans R Soc Lond B Biol Sci. 2003;358(1436):1397-402 (discussion 1402).

44. Nichols J, Silva J, Roode M, Smith A. Suppression of Erk signalling promotes ground state pluripotency in the mouse embryo. Development. 2009;136(19):3215-22.

45. Burdon T, Stracey C, Chambers I, Nichols J, Smith A. Suppression of SHP-2 and ERK signalling promotes self-renewal of mouse embryonic stem cells. Dev Biol. 1999;210(1):30-43.

46. Martello G, Sugimoto T, Diamanti E, Joshi A, Hannah R, Ohtsuka S, et al. Esrrb is a pivotal target of the Gsk3/Tcf3 axis regulating embryonic stem cell self-renewal. Cell Stem Cell. 2012;11(4):491-504.

47. Li Z, Fei T, Zhang J, Zhu G, Wang L, Lu D, et al. BMP4 Signaling Acts via dual-specificity phosphatase 9 to control ERK activity in mouse embryonic stem cells. Cell Stem Cell. 2012;10(2):171-82.

48. Chazaud C, Yamanaka Y, Pawson T, Rossant J. Early lineage segregation between epiblast and primitive endoderm in mouse blastocysts through the Grb2-MAPK pathway. Dev Cell. 2006;10(5):615-24.

49. Lu C-W, Yabuuchi A, Chen L, Viswanathan S, Kim K, Daley GQ. Ras-MAPK signaling promotes trophectoderm formation from embryonic stem cells and mouse embryos. Nat Genet. 2008:40(7):921-6.

50. Yamanaka Y, Lanner F, Rossant J. FGF signal-dependent segregation of primitive endoderm and epiblast in the mouse blastocyst. Development. 2010;137(5):715-24.

51. Vallier L, Touboul T, Chng Z, Brimpari M, Hannan N, Millan E, et al. Early cell fate decisions of human embryonic stem cells and mouse epiblast stem cells are controlled by the same signalling pathways. PLoS ONE. 2009;4(6):e6082.

52. LaVaute TM, Yoo YD, Pankratz MT, Weick JP, Gerstner JR, Zhang SC. Regulation of neural specification from human embryonic stem cells by BMP and FGF. STEM CELLS. 2009;27(8):1741-9.

53. Matulka K, Lin H-H, Hř́bková $H$, Uwanogho D, Dvorák P, Sun YM. PTP1B is an effector of activin signaling and regulates neural specification of embryonic stem cells. Cell Stem Cell. 2013;13:706-19.

54. Guilak F, Cohen DM, Estes BT, Gimble JM, Liedtke W, Chen CS. Control of stem cell fate by physical interactions with the extracellular matrix. Cell Stem Cell. 2009;5(1):17-26.

55. Li X, Zhu L, Yang A, Lin J, Tang F, Jin S, et al. Calcineurin-NFAT signaling critically regulates early lineage specification in mouse embryonic stem cells and embryos. Cell Stem Cell. 2011;8(1):46-58.

56. Zhang F, Wang LP, Brauner M, Liewald JF, Kay K, Watzke N, et al. Multimodal fast optical interrogation of neural circuitry. Nature. 2007:446(7136):633-9.

57. Lipskaia L, Lompre AM. Alteration in temporal kinetics of $\mathrm{Ca} 2+$ signaling and control of growth and proliferation. Biol Cell. 2004;96(1):55-68.

\section{Publisher's Note}

Springer Nature remains neutral with regard to jurisdictional claims in published maps and institutional affiliations.
Ready to submit your research? Choose BMC and benefit from:

- fast, convenient online submission

- thorough peer review by experienced researchers in your field

- rapid publication on acceptance

- support for research data, including large and complex data types

- gold Open Access which fosters wider collaboration and increased citations

- maximum visibility for your research: over 100M website views per year

At BMC, research is always in progress.

Learn more biomedcentral.com/submissions 